УДК: 330.837-026.15

DOI: 10.26697/ijes.2019.2.39

\section{Інститут довіри як невід'смний інституціональний чинник креативної економіки}

Доцент Лисюк В. С.

${ }^{1}$ Рівненський інститут слов'янознавства, Україна

\section{Резюме \\ Вступ:}

Аналізу сутності категорії “довіра”, обгрунтуванню значимості інституту довіри в умовах поглиблення глобалізації присвячено багато наукових праць. Однак обгрунтуванню інституту довіри як важливого чинника ефективної взаємодії громадян, бізнесу і держави, що вирішальним чином впливає на економічне та інституціональне середовище в суспільстві, на ефективність державного управління в частині реалізації основної цілі зростання суспільного добробуту громадян, досліджено недостатньо.

Мета дослідження: обгрунтування необхідності інституту довіри в Україні 3 метою побудови демократичного суспільства, реалізації добробуту громадян в умовах креативної економіки.

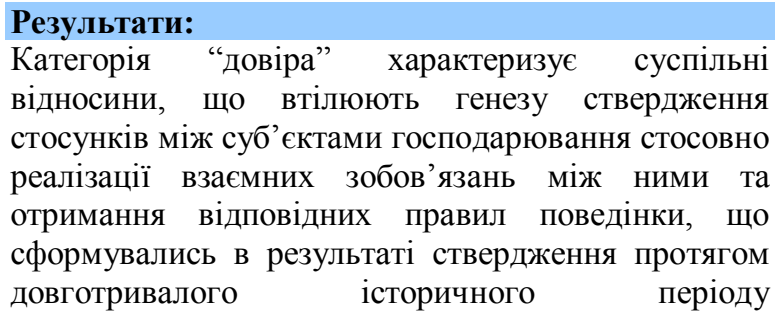
формалізованих і неформалізованих інститутів.

Історично інститут довіри формується під впливом ствердження у громадян наукового усвідомлення реальної дійсності, визначення свого ставлення до інших людей та адекватної реакції оточуючого середовища

Ефективне та стабільне відтворення національної економіки забезпечується дієздатністю відповідних інститутів, серед яких фундаментальним імперативом суспільства виступає інститут довіри. Для різних національних економік зміст і реалізація інституту довіри неоднакова, що обумовлено характером інституційного середовища та його архітектонікою, що формується в кожній країні під впливом еволюції багатьох національних, культурних, політичних, соціальних і моральних чинників.

Відсутність в населення переконливої віри в своє майбутнє, що обумовлено недовірою до економічної та соціальної політики, законодавчої, виконавчої та судової гілок влади, деморалізує суспільство, подавляє творчий потенціал людини. Синергічний ефект недовіри дезорганізує суспільство в цілому, що призводить до архаїчності в організації та управлінні національною економікою, а значить, суттєвим чином знижує іiі потенціальну можливість до конкурентної боротьби на світовому ринку.

Недовіра 3 боку суспільства до державних інститутів супроводжується різного роду порушеннями громадського порядку, недовіра до роботодавців знижує ініціативу, технологічну дисципліну та й продуктивність праці найманих працівників, що підриває конкурентоспроможність національного товаровиробника.

Існування в суспільстві груп економічного i політичного впливу, інтереси яких представляють відповідні партії, які будують свою політичну кар'єру в більшій мірі на незадоволені суспільства владою, не маючи при цьому конструктивних ідей прогресивних змін у суспільстві, проголошуючи тільки популістські тези, ускладнює формування довіри до влади в Україні. Тобто політичні партії працюють не на зміцнення довіри населення та бізнесу до влади, а, навпаки, спекулюють на їхній недовірі.

Повернення капіталів 3-за кордонів і введення в обіг тих, що бездіяльно знаходяться у населення як засіб страхування недовіри до владної та банківської систем, могли б змінити стан економіки країни.

Формування інституту довіри потребує відмовитися від роздачі владою обіцянок, яких вона не виконує і таким чином знижує кредит довіри державних інститутів у своїх громадян, підриває можливість проведення ефективних реформ.

\begin{abstract}
Висновки:
Отже, головним завданням сьогодення для України $\epsilon$ забезпечення довіри до державних інститутів, без чого неможливо побудувати ефективну креативну економіку, демократичне суспільство. Для цього потрібно формування таких соціальних зв'язків, які б забезпечили максимально припустимий рівень взаємодії суб'єктів економічної діяльності при розв'язанні завдань виробничого i соціального змісту, рівноправну довірчу спрямованість цієї взаємодії.
\end{abstract}

Інформація про автора:

Лисюк Володимир Сергійович - кандидат економічних наук, доцент кафедри економіки та маркетингу, Рівненський інститут слов'янознавства, Рівне, Україна.

Наукові інтереси: проблеми публічного управління економікою.

Автор-Кореспондент:

Лисюк Володимир Сергійович

Email Автора-Кореспондента:

lysyukrivne@gmail.com 